\title{
BIG COFFEE VL.: SEED DESICCATION TOLERANCE, SIEVE CLASSIFICATION, AND PHYSIOLOGICAL QUALITY
}

\author{
Ana Cristina de Souza ${ }^{1}$, Sttela Dellyzete Veiga Franco da Rosa², Amanda Lima Vilela ${ }^{3}$, \\ Madeleine Alves de Figueiredo ${ }^{4}$, Ana Luiza de Oliveira Vilela ${ }^{5}$, Ricardo Stéphano Filho ${ }^{6}$, \\ Milene Alves de Figueiredo Carvalho ${ }^{7}$
}

(Received: June 26, 2018; accepted: August 13, 2018)

\begin{abstract}
A coffee plant producing large fruit, seeds, and leaves in relation to conventional coffee plants, possibly generated by genetic mutation, was named Big Coffee VL. Seeds of this coffee plant were classified by size and used to establish the crop, whose progenies were designated as Big Coffee VL. large, Big Coffee VL. medium, and Big Coffee VL. small. The aim in this study was to investigate desiccation tolerance, together with size classification, and evaluate the physiological quality of the seeds of this progeny. Seeds of each type of Big Coffee VL. and of the cultivar Topázio were collected. High moisture seeds and seeds dried to $11 \%$ moisture content were evaluated to assess desiccation tolerance. Dried seeds of each Big Coffee VL. progeny and of the Topázio cultivar were classified by size in sieve testing using oblong screens for separation of peaberry seeds, and circular sieves from 22 to 12 for separation of flat seeds. All seeds were subjected to physiological evaluation through the germination test and determination of seedling dry matter. A completely randomized experimental design (CRD) was used; results were subjected to analysis of variance and means compared by the Scott-Knott test. Big Coffee VL. seeds tolerate desiccation to moisture content of $11 \%$ wet basis. Seeds of the Topázio cultivar have better physiological performance than seeds of the Big Coffee VL progenies. The bigger the seeds of Big Coffee VL., the better their physiological performance, exhibiting greater seedling dry matter.
\end{abstract}

Index terms: Coffea arabica L, seed size, germination test, vigor, particle size analysis sieves.

\section{BIG COFFEE VL.: TOLERÂNCIAA DESSECAÇÃO DE SEMENTES, CLASSIFICAÇÃO EM PENEIRAS E QUALIDADE FISIOLÓGICA}

RESUMO: Uma planta de café que produz grandes frutos, sementes e folhas em relação ao cafeeiro convencional, possivelmente gerada por mutação genética, foi denominada Big Coffee VL. As sementes deste cafeeiro foram classificadas por tamanho e usadas para estabelecer a cultura, cujas progênies foram designadas como Big Coffee VL. grande, Big Coffee VL. médio, e Big Coffee VL. pequeno. O objetivo neste estudo foi investigar a tolerância à dessecação, juntamente com a classificação por tamanho, e avaliar a qualidade fisiológica das sementes destas progênies. Sementes de cada tipo de Big Coffee VL. e da cultivar Topázio foram coletadas. Sementes com alta umidade e sementes secas a $11 \%$ de umidade foram utilizadas para avaliar a tolerância à dessecação. Sementes secas de cada progênie Big Coffee VL e a cultivar Topázio foram classificadas por tamanho, jogo de peneiras, utilizando telas oblongas para separação de sementes tipo moca e peneiras circulares de 22 a 12 para separação de sementes chatas. Todas as sementes foram submetidas à avaliação fisiológica por meio do teste de germinação e determinação da matéria seca das plântulas. Um delineamento experimental foi inteiramente casualizado (DIC) foi utilizado; os resultados foram submetidos à análise de variância e as médias comparadas pelo teste de Scott-Knott. Sementes de Big Coffee VL. toleram dessecação para um teor de umidade de $11 \%$ base úmida. Sementes da cultivar Topázio apresentam melhor desempenho fisiológico que as sementes das progênies de Big Coffee VL. Quanto maiores as sementes de Big Coffee VL., melhor seu desempenho fisiológico, exibindo maior massa seca de plântulas.

Termos para indexação: Coffea arabica L, tamanho da semente, teste de germinação, vigor, peneiras de análise granulométrica.

\section{INTRODUCTION}

Coffee is one of the most important agricultural commodities exported and one of the beverages most consumed in the world (CARDOSO et al. 2016). It is an extremely important product in Brazil as an exported product, a source of income, a source of employment, and a channel of manual labor in the rural area
(SANTOS et al., 2009). Coffee fields in Brazil were formed from the arabica cultivar (Coffea arabica $\mathrm{L}$. var. typica), the first to be introduced in the country. Little by little, coffee fields began to diversify through introduction of new cultivars (MARTINS et al., 1992).

As the crop is so important for Brazil, a concern is the low tolerance of coffee seeds to desiccation and to storage; they are classified as

1,3,4,5,6 Universidade Federal de Lavras/UFLA - Departamento de Agricultura/DAG - Cx. P. 3037 - 37.200-000 - Lavras - MG acstina@yahoo.com.br, amanda.li.vi@hotmail.com, madeleineafigueiredo@gmail.com, anavilela_bio@hotmail.com, ricardodestephano@hotmail.com

2,7Embrapa Café, PqEB - Av. W3 Norte (Final), Asa Norte, Ed. Sede Embrapa - 70.770-901 - Brasília - DF - sttela.rosa@embrapa.br, milene.carvalho@embrapa.br

Coffee Science, Lavras, v. 13, n. 4, p. 510 - 518, oct./dec. 2018 
intermediate seeds (ELLIS et al., 1990). For that reason, preserving coffee seeds has become a big challenge (BERJAK; PAMMENTER, 2013), especially a problem for seedling producers, who need to conserve seeds up to the suitable time for sowing. To try to resolve this problem, studies are performed for the purpose of finding new characteristics in seeds of new coffee cultivars and of characterizing their drying conditions and to what extent they maintain longevity.

In the midst of a crop field of the cultivar Acaiá (C. arábica) in Capitólio, $\mathrm{MG}$, a coffee plant that had larger than normal fruit and leaves, presumably through having undergone a mutation, was identified and named Big Coffee VL. Seeds of this coffee plant were sown in Piumhí, MG. In the new crop generated, high segregation was observed and the plants were classified, taking into account the size of fruit and leaves and plant height. The seeds were classified by size and used for establishing new crops at the Universidade Federal de Lavras, in Lavras, MG. The plants were classified as Big Coffee VL. small, Big Coffee VL. medium, and Big Coffee VL. large, for the purpose of beginning studies on this coffee plant (CASTANHEIRA et al., 2016; SILVA et al., 2016).

The increase in the size of coffee seeds/beans is one of the purposes of studies in coffee breeding, which may add greater value to the product (GUEDES et al., 2013). There are few studies on the relationship between the size and quality of the seeds of the Coffea species. Therefore, it is important to assess the physiological performance of the seeds of Big Coffee VL., since its seeds are larger. This will allow study of the relationship between seed size and physiological quality, comparing Big Coffee seeds with common coffee seeds. The aim in this study was to investigate desiccation tolerance, classify seeds by size, and evaluate the physiological quality of the seeds of these plants, investigating the interaction between the size of the seeds and physiological performance.

\section{MATERIALS AND METHODS}

\section{Harvest of fruit and obtaining seeds}

Fruit from the Big Coffee VL. progenies and from the cultivar Topázio, both of the species C.arabica, were harvested manually in the cherry maturity stage in two periods, July 2016 and May 2017, in a crop field set up at the Universidade Federal de Lavras.
Fruit from 5 progenies considered as the large type (L), 5 progenies considered as the medium type $(\mathrm{M})$, and 5 progenies considered as the small type $(\mathrm{S})$ were collected at random. For the control, fruit from 5 plants of the Topázio cultivar, of the species $C$. arabica were collected. These plants were also chosen at random.

The fruit from each plant was pulped and fully washed manually and separately so that there was no mixing. Mucilage was removed by fermentation in water in a fermentation chamber at $25^{\circ} \mathrm{C}$ for 24 hours, until all the mucilage was liquefied. After that, the seeds were washed in running water for total removal of the mucilage.

To remove surface water, all the seeds were placed in a single layer over a screen and kept in the shade, always with attention to identification of the seeds from each plant. After surface drying, initial moisture content of the seeds was determined, which was around $48 \% \mathrm{wb}$. These seeds were then studied for desiccation tolerance and the effect of seed size on physiological performance.

\section{Study of desiccation tolerance of seeds of Big Coffee VL}

The seeds of Big Coffee VL. small, Big Coffee VL. medium, and Big Coffee VL. large, with initial moisture content of $48 \%$ wb were divided into two parts; one of the parts was dried in a mechanical dryer, and the other part was used without drying.

Drying was performed by forced convection in fixed bed dryers composed of six square trays with a perforated bottom and sides of $0.35 \mathrm{~m}$ and depth of $0.4 \mathrm{~m}$, with uniform airflow. The airflow throughout the seed drying process was monitored by a paddle wheel anemometer, which was regulated and maintained at $24 \mathrm{~m}^{3} \cdot \mathrm{min}^{-1} \cdot \mathrm{m}^{-2}$. Temperature was adjusted and controlled by thermostats and an electronic panel, which were constantly monitored with the aid of mercury thermometers placed within the seed mass. The seeds were dried at a temperature of approximately $38^{\circ} \mathrm{C}$ until reaching a moisture content of $11 \% \mathrm{wb}$.

Moisture content was determined by the laboratory oven method at $105^{\circ} \mathrm{C}$ for 24 hours (BRASIL, 2009), with two replications of 5 seeds for each treatment. The results were expressed in percentage based on the wet weight of the seeds.

The samples were monitored until reaching the desired moisture content of $11 \%(\mathrm{wb})$. 
The dried seeds and those not subjected to drying of each S, M, and L progeny and of the Topázio cultivar were evaluated physiologically by the germination test and by determination of seedling dry matter.

In the germination test were used four replications of 25 seeds of each treatment, which were sown in germination paper moistened with distilled water at 2.5 times the weight of the dry paper. The rolls of germination paper were placed in a germinator at a temperature of $30^{\circ} \mathrm{C}$ in the presence of light (BRASIL, 2009).

Percentages of root emergence at 15 days and percentage of normal seedlings at 30 days after sowing were determined; normal seedlings were considered those that had a main root and at least two lateral roots. The germination test also determined the percentage of strong normal seedlings, which were considered those that had a hypocotyl with at least three centimeters length, and the percentage of seedlings with expanded cotyledonary leaves at 45 days after sowing.

Seedling dry matter was determined at the end of the germination test in the seedlings with expanded cotyledonary leaves; the number of seeds sown was considered in the calculation. The shoots of the seedlings were separated from the roots using a scalpel and the plant matter was placed in paper bags and dried in a forced air circulation oven at $60^{\circ} \mathrm{C}$ for five days, until reaching constant weight. Dry matter was determined on a precision balance.

\section{Big Coffee VL. seed classification by size and physiological quality}

For size classification, seeds collected in 2017 were used from plants of five progenies named in the field as P26, P29, P31, P10, and P32, considered to be of the Big Coffee VL. small type; five named as M11, M17, M27, M8, and M23, progenies of the Big Coffee VL. medium type; and five named as G22, G18, G21, G19, and G25, progenies of the Big Coffee VL. large type. Topázio seeds were collected from plants chosen at random, and their plants do not have a specific designation in the field. A sieve analysis test was carried out on seeds without parchment and with moisture content of approximately $11 \%$ using oblong particle size analysis sieves of numbers 17,15 , and 13 for separation of peaberry type seeds, and circular particle size analysis sieves of numbers $22,21,20,19,18,17,16,15,14$, 13 , and 12 for separation of flat seeds. For seed classification, sieves of numbers $11,12,13$, and 14 were considered as small sieves; 15 and 16 as medium number sieves, and sieves 17, 18, 19, 20,21, and 22 as large number sieves (BRASIL, 2003). The seeds classified by size were evaluated physiologically through the germination test, performed as already described.

\section{Experimental design and statistical analysis}

For the study of desiccation tolerance of Big Coffee VL seeds the experimental design was completely randomized in a $2 \times 4$ factorial arrangement (with and without drying; and the progenies $\mathrm{S}, \mathrm{M}$, and $\mathrm{L}$ and the Topázio cultivar).

In the study of the effects of seed size on physiological quality, the experimental design was completely randomized in a $2 \times 6$ factorial arrangement (seeds of the Big Coffee VL. and of the Topázio cultivar progenies; and sieve numbers from 13 to 18$)$.

For the study of the effects of seed sizes of the Big Coffee VL. progeny on physiological quality, the experimental design was completely randomized, with 9 sieve numbers (from 12 to 20) and four replications. The data were subjected to analysis of variance and the qualitative means were grouped by the Scott-Knott test at 5\% probability (FERREIRA, 2011).

\section{RESULTS AND DISCUSSION}

\section{Study of desiccation tolerance of Big Coffee VL seeds}

The physiological quality of the seeds of the Big Coffee VL. S, M, and L progenies and of the Topázio cultivar was evaluated before and after drying to $11 \% \mathrm{wb}$ of moisture content. Analysis of variance showed that for most of the variables of physiological quality, there was significant interaction between the progeny or cultivar and drying factors. There was no interaction between the factors studied only for the variables shoot dry matter and root dry matter; however, there was significance for each factor separately (Table 1).

The seeds of the $\mathrm{S}$ progeny and of the Topázio cultivar, with moisture of approximately $48 \% \mathrm{wb}$, which had not been dried, had a higher percentage of root emergence than the others. Nevertheless, after drying, there was no difference in the values of this variable among the seeds of the progenies studied (Table 1).

At 30 days after sowing, the seeds without drying also had better results of percentage of normal seedlings in the germination test for the S progeny and for the control, represented by the Topázio cultivar. When undergoing drying, only the control seeds stood out from the others (Table 1). 
TABLE 1 - Percentage of root emergence (RE), normal seedlings (NS), strong normal seedlings (SNS), and of seedlings with expanded cotyledonary leaves (ECL) from seeds of Big Coffee VL., S, M, and L progenies and of the Topázio cultivar, without drying and dried to the moisture content of $11 \%$ (wet basis).

\begin{tabular}{lcccccccc}
\hline & \multicolumn{2}{c}{ RE } & \multicolumn{2}{c}{ NS } & \multicolumn{2}{c}{ SNS } & \multicolumn{2}{c}{ ECL } \\
\cline { 2 - 10 } $\begin{array}{l}\text { Big C. } \\
\text { Cultivar }\end{array}$ & $\begin{array}{c}\text { Without } \\
\text { drying }\end{array}$ & $\begin{array}{c}\text { With } \\
\text { drying }\end{array}$ & $\begin{array}{c}\text { Without } \\
\text { drying }\end{array}$ & $\begin{array}{c}\text { With } \\
\text { drying }\end{array}$ & $\begin{array}{c}\text { Without } \\
\text { drying }\end{array}$ & $\begin{array}{c}\text { With } \\
\text { drying }\end{array}$ & $\begin{array}{c}\text { Without } \\
\text { drying }\end{array}$ & $\begin{array}{c}\text { With } \\
\text { drying }\end{array}$ \\
\hline Large & $53 \mathrm{Cb}$ & $72 \mathrm{Aa}$ & $19 \mathrm{Cb}$ & $45 \mathrm{Ba}$ & $00 \mathrm{Bb}$ & $11 \mathrm{Aa}$ & $33 \mathrm{Aa}$ & $18 \mathrm{Aa}$ \\
\hline Medium & $56 \mathrm{Cb}$ & $69 \mathrm{Aa}$ & $24 \mathrm{Cb}$ & $43 \mathrm{Ba}$ & $1 \mathrm{Bb}$ & $10 \mathrm{Aa}$ & $36 \mathrm{Aa}$ & $12 \mathrm{Ab}$ \\
\hline Small & $80 \mathrm{Ba}$ & $81 \mathrm{Aa}$ & $54 \mathrm{Ba}$ & $54 \mathrm{Ba}$ & $13 \mathrm{Aa}$ & $10 \mathrm{Aa}$ & $45 \mathrm{Aa}$ & $60 \mathrm{Aa}$ \\
\hline Topázio & $93 \mathrm{Aa}$ & $75 \mathrm{Ab}$ & $72 \mathrm{Aa}$ & $66 \mathrm{Aa}$ & $5 \mathrm{Ba}$ & $6 \mathrm{Aa}$ & $42 \mathrm{Ab}$ & $64 \mathrm{Aa}$ \\
\hline & & 9.87 & & 27.34 & & 61.25 & & 32.51 \\
\hline
\end{tabular}

Means followed by the same uppercase letter in the column and same lowercase letter in the line belong to the same cluster at the level of 5\% probability according to the Scott Knott test.

Considering evaluation of seed vigor, moist seeds of the S progeny had a higher percentage of strong normal seedlings compared to seeds of the other progenies and of the Topázio cultivar.

After drying, there was no difference between the values of the different progenies and of the control seeds. For the results of percentage of seedlings with expanded cotyledonary leaves at 45 days after sowing, the seeds of the $\mathrm{S}, \mathrm{M}$, and $\mathrm{L}$ progenies and of the control had statistically equal values, regardless of whether or not they were dried.

In general, both seeds of the progenies and of the control had better physiological quality, evaluated by germination and vigor, after being dried, which can be verified by the variables of percentage of root emergence, percentage of strong normal seedlings, and seedlings with expanded cotyledonary leaves. Physiological performance also improved after seed drying for seeds of the $M$ and $\mathrm{L}$ progenies.

Better physiological performance can be explained by greater ease of removal of the parchment after drying of seeds to lower moisture contents, minimizing the possibility of damage to seeds. Another explanation would be lower proliferation of fungi in the germination test in the dried seeds, which had better germination and vigor. Rosa et al. (2005) found that in coffee seeds stored at a higher moisture content, there may be fungi and losses in seedling development, resulting in lower germination percentages.

For all the variables analyzed, the seeds of the S progenies and Topázio cultivar (control) had better results, regardless of having been dried or not (Table 1). Coelho et al. (2017) investigated the quality of dried seeds and concluded that water contents below $0.11 \mathrm{~g} \mathrm{H}_{2} \mathrm{O} \mathrm{g}^{-1}$ (dry weight-dw) and above $0.43 \mathrm{~g} \mathrm{H}_{2} \mathrm{O} \mathrm{g}^{-1} \mathrm{dw}^{2}$ hurt the physiological quality of coffee seeds, regardless of the type of drying, temperature, and period of storage. Figueiredo (2017) observed that C.arabica. seeds have good physiological quality when dried to the moisture content of $20 \%$, being tolerant to the cryopreservation stresses. Corroborating this literature, seeds of Big Coffee VL. tolerate desiccation to the moisture content of $11 \% \mathrm{wb}$; however, smaller seeds have better physiological performance. Coelho et al. (2015) state that drying losses for physiological quality of coffee seeds depend on the speed with which water is removed and on the final moisture content of the seeds.

Subjecting seeds to the drying process allowed an increase in shoot dry matter and root dry matter of the plants studied (Table 2).

\section{Classification by size and physiological quality of Big Coffee VL seeds}

Seeds of the Big Coffee VL. S, M, and $\mathrm{L}$ progenies and of the Topázio cultivar were classified regarding size through the sieve retention test, and the results are shown in Table 3. It can be seen from the percentages of retention in each sieve that there are small, medium, and large seeds in all the Big Coffee VL. progenies, even if in varied proportions. This is probably due to the segregation that still exists in these plants.

Nevertheless, progeny L, classified in the field as having large seeds, had $61.16 \%$ of seeds retained in the sieves with numbers considered large (sieves 17 to 22 ), $31.70 \%$ in the medium numbered sieves (sieves 15 and 16), and 6.88\% in the small numbered sieves (sieves 11 to 14) (Table 3). 
TABLE 2 - Shoot dry matter and root dry matter of seeds of Big Coffee VL. and of the Topázio cultivar, without drying and dried to the moisture content of $11 \%$ (wet basis).

\begin{tabular}{lll}
\hline Drying & Shoot dry matter & Root dry matter \\
\hline With drying & $32.67 \mathrm{~A}$ & $5.68 \mathrm{~A}$ \\
Without drying & $16.52 \mathrm{~B}$ & $2.58 \mathrm{~B}$ \\
\hline CV $(\%)$ & 34.30 & 39.03 \\
\hline
\end{tabular}

Means followed by the same letter in the column belong to the same cluster at the level of $5 \%$ probability according to the Scott Knott test.

TABLE 3 - Percentage of seeds of the progenies S, M, and L of Big Coffee VL., and of the Topázio cultivar of different sizes, classified by retention in particle size sieves.

\begin{tabular}{|c|c|c|c|c|c|c|c|c|c|c|c|c|}
\hline \multicolumn{13}{|c|}{ Sieve Number } \\
\hline & \multicolumn{4}{|c|}{ Small } & \multicolumn{2}{|c|}{ Medium } & \multicolumn{6}{|c|}{ Large } \\
\hline & 11 & 12 & 13 & 14 & 15 & 16 & 17 & 18 & 19 & 20 & 21 & 22 \\
\hline B. Coffee L & 0.00 & 0.22 & 2.54 & 4.12 & 10.9 & 20.8 & 27.6 & 19.7 & 10.8 & 2.96 & 0.02 & 0.08 \\
\hline B.Coffee M & 0.06 & 0.96 & 2.67 & 7.63 & 11.9 & 18.1 & 24.9 & 20.3 & 9.50 & 3.55 & 0.13 & 0.09 \\
\hline B. Coffee S & 0.08 & 1.50 & 4.18 & 11.1 & 18.3 & 31.7 & 22.8 & 8.84 & 1.27 & 0.03 & 0.00 & 0.06 \\
\hline Topázio & 0.00 & 1.07 & 4.49 & 9.45 & 26.3 & 36.6 & 17.4 & 3.35 & 0.93 & 0.11 & 0.00 & 0.00 \\
\hline
\end{tabular}

As for progeny $\mathrm{M}$, the greatest proportion of the seeds was retained in large sieves, with $58.47 \%$; in medium numbered sieves, the percentage was $30.00 \%$; and small numbered sieves represented $11.32 \%$. The small, medium, and large numbered sieves retained $16.86 \%, 50.00 \%$, and $33.00 \%$ of the seeds of progeny $\mathrm{S}$, respectively.

For the Topázio cultivar, the results were similar to those of the S progeny; i.e., $15.00 \%$ of the seeds were retained in the small sieves; $62.90 \%$ in the mean numbered sieves; and $21.70 \%$ in the large sieves. The largest proportion of seeds was retained in the medium sieves.

Seeds of the Topázio cultivar were not retained in sieves 11,21 , and 22 , and few seeds were retained in sieves 12,19, and 20. Likewise for the Big Coffee VL. progenies, few seeds were retained in sieves 11,21 , and 22 . Thus, the number of seeds from these sieves was not sufficient to perform the germination test.

Classification of the coffee seeds/beans according to size is relevant for uniform roasting. For international trade, coffee beans from sieve numbers 13 to 20 are accepted; however, there is a tendency among exporters to prefer sieve sizes greater than 16 (LAVIOLA et al. 2006;
ROTONDANO et al. 2005). Dias Caldas et al. (2018), who worked with classification regarding the size of C.arábica L., cv. Travessia seeds, observed that seeds retained in larger screens were significantly influenced by irrigation and fertilization management practices.

For the sieve-classified seeds, both for Big Coffee VL. and for the Topázio cultivar, physiological performance was evaluated. Analysis of variance showed that for the variables of root emergence, normal seedlings, and seedlings with expanded cotyledonary leaves, there was no significant interaction among the progeny/cultivar factors and sieve number, but there was significance of these factors separately (Table 4). The Topázio cultivar exhibited better physiological performance than the seeds of the Big Coffee VL. progenies, according to the values of root emergence, of normal seedlings, and of seedlings with expanded cotyledonary leaves (Table 4).

Even though significant differences were not observed on physiological performance of the seeds classified by size, a tendency of increase in quality with a decrease in the sieve size number can be seen (Table 4). 
Big coffee vl.: seed desiccation tolerance, sieve ...

TABLE 4 - Effect of the Big Coffee VL. progeny or of the Topázio cultivar and of the number of sieve size classification on root emergence, normal seedlings, and seedlings with expanded cotyledonary leaves of the seeds.

\begin{tabular}{cccc}
\hline Progeny/Cultivar & Root Emergence & Normal Seedlings & Expanded Cotyledonary Leaves \\
\hline Big Coffee VL. & $85.6 \mathrm{~b}$ & $72.5 \mathrm{~b}$ & $67.6 \mathrm{~b}$ \\
Topázio & $92.8 \mathrm{a}$ & $82.3 \mathrm{a}$ & $75.8 \mathrm{a}$ \\
\hline CV $(\%)$ & 8.04 & 11.70 & 11.93 \\
\hline Sieve & Root Emergence & Normal Seedlings & Expanded Cotyledonary Leaves \\
\hline 18 & $85.5 \mathrm{a}$ & $77.5 \mathrm{a}$ & $71.5 \mathrm{a}$ \\
17 & $87.0 \mathrm{a}$ & $75.0 \mathrm{a}$ & $68.0 \mathrm{a}$ \\
16 & $91.5 \mathrm{a}$ & $76.5 \mathrm{a}$ & $75.5 \mathrm{a}$ \\
15 & $89.5 \mathrm{a}$ & $77.5 \mathrm{a}$ & $71.0 \mathrm{a}$ \\
14 & $89.0 \mathrm{a}$ & $79.0 \mathrm{a}$ & $72.0 \mathrm{a}$ \\
13 & $93.0 \mathrm{a}$ & $79.0 \mathrm{a}$ & $72.5 \mathrm{a}$ \\
\hline CV $(\%)$ & 8.04 & 11.70 & 11.70
\end{tabular}

Means followed by the same letter in the column belong to the same cluster according to the Scott Knott test at the level of $5 \%$ probability.

The seeds of the Topázio cultivar exhibited a higher percentage of normal seedlings, as well as higher vigor, evaluated by the percentage of root emergence and of seedlings with expanded cotyledonary leaves at 45 days. Concerning the effects of sieve size number, the large sized seeds, $17 \mathrm{~mm}$ and greater, the medium sized seeds, of 15 and $16 \mathrm{~mm}$, and the small sized seeds, of 13 and $14 \mathrm{~mm}$ (BRASIL, 2003) exhibited differentiated physiological performances, with better germination and vigor in the small sized seeds.

In studies on physiological performance according to coffee (C. arabica) seed size, there were no significant differences in the results of germination of seeds produced under different conditions of soil, temperature, and rainfall in the phases of fruit expansion and growth (FAVARIN et al., 2003). According to the authors, the separation of coffee seeds by size is a necessary but not sufficient condition for adequate selection for estimation of seed physiological potential and the formation of quality seedlings.

Flores et al. (2014) and Pardo et al. (2015) observed that smaller sized seeds of brauna and of soybean, respectively, have low physiological quality compared to those of larger sizes. According to the results presented, plants or progenies arising from seeds with sizes corresponding to lower sieve numbers will not necessarily have lower vigor or less viability than the others.
In this study, the results of percentage of seedlings with expanded cotyledonary leaves, an indication of seedling vigor, do not differ statistically according to sieve size, but did exhibit higher absolute values, the overall mean being $71 \%$.

For the variables of shoot and root dry matter, there was also no significant effect of the interaction of the progeny or cultivar factors and sieve number on physiological response (Table 5). Nevertheless, there were significant differences among the seeds of different sizes and different progenies/cultivar.

The seedlings of the Topázio cultivar had greater shoot dry matter than the seedlings of the Big Coffee VL. progenies, and also had better germination and vigor results (Table 4). Analysis of the effects of sieve number and consideration of the sieves common to the Topázio cultivar and Big Coffee VL. progenies on seedling dry matter showed that the seedlings coming from medium and high sieve size, of size 15 to 18 , obtained higher values than small sieves, of size 13 and 14 (Table 5).

Seedlings coming from larger seeds had more developed shoots and root system than seedlings from seeds of smaller sieve sizes, and this was reflected in the values for dry matter. A less developed root system in tropical and/or subtropical species that produce recalcitrant seeds may occur due to the presence of reactive oxygen species (BERJAK; SERSHEN; PAMMENTER; 2011). 
Seeds of the Big Coffee VL. progenies classified by size, of number 12 to 20 , were evaluated in regard to physiological performance, and the results are shown in Table 6. In this analysis, seeds of the Topázio cultivar were not considered. Significant differences were observed among the sieve sizes only for the results of seedling dry matter (Table 6); the seedlings coming from seeds of higher sieve size had greater vigor than those from smaller sieve sizes, unlike the analysis in which seeds of the Topázio cultivar were compared with those of Big Coffee VL. (Table 5).

According to these variables that indicate vigor, a decline in the physiological quality of Big
Coffee VL. seeds is observed along with reduction in sieve size, i.e., seeds retained in sieves with larger openings had higher vigor. It is noteworthy that among the Big Coffee VL. seeds classified by size, there was a positive effect of greater size on physiological quality. However, when these seeds were compared to Topázio cv seeds, with same size, there was greater influence of the cultivar, in detriment of the effects of seed size. In other words, when the physiological quality of the seeds of the progenies and cultivar is compared regarding size, there is predominance of the effect of the cultivar; the seeds of the Topázio cultivar exhibit better physiological quality.

TABLE 5 - Effect of the Big Coffee VL. progeny or of the Topázio cultivar and of the number of sieve size classification on shoot dry matter and root dry matter .

\begin{tabular}{ccc}
\hline Progeny/Cultivar & Shoot Dry Matter & Root Dry Matter \\
\hline Big Coffee VL. & $0.70 \mathrm{~b}$ & $0.14 \mathrm{~b}$ \\
Topázio & $0.80 \mathrm{a}$ & $0.17 \mathrm{a}$ \\
\hline CV (\%) & 13.95 & 24.09 \\
\hline Sieve & Shoot Dry Matter & Root Dry Matter \\
\hline 18 & $0.83 \mathrm{a}$ & $0.20 \mathrm{a}$ \\
17 & $0.80 \mathrm{a}$ & $0.17 \mathrm{a}$ \\
16 & $0.81 \mathrm{a}$ & $0.14 \mathrm{~b}$ \\
15 & $0.68 \mathrm{~b}$ & $0.13 \mathrm{~b}$ \\
14 & $0.70 \mathrm{~b}$ & $0.16 \mathrm{a}$ \\
13 & $0.67 \mathrm{~b}$ & $0.11 \mathrm{~b}$ \\
\hline CV $(\%)$ & 13.95 & 24.09
\end{tabular}

Means followed by the same letter in the column belong to the same cluster according to the Scott Knott test at the level of $5 \%$ probability.

TABLE 6 - Shoot dry matter and root dry matter of seedlings coming from seeds of the Big Coffe VL. progenies classified in different particle size sieves.

\begin{tabular}{cccc}
\hline & Sieve Number & Shoot Dry Matter & Root Dry Matter \\
\hline \multirow{3}{*}{ Large } & 20 & $1.07 \mathrm{a}$ & $0.23 \mathrm{a}$ \\
& 19 & $0.82 \mathrm{~b}$ & $0.19 \mathrm{a}$ \\
& 18 & $0.82 \mathrm{~b}$ & $0.20 \mathrm{a}$ \\
Medium & 17 & $0.73 \mathrm{c}$ & $0.17 \mathrm{~b}$ \\
& 16 & $0.81 \mathrm{~b}$ & $0.14 \mathrm{~b}$ \\
\hline \multirow{2}{*}{ Small } & 15 & $0.61 \mathrm{~d}$ & $0.09 \mathrm{c}$ \\
\hline & 14 & $0.67 \mathrm{c}$ & $0.14 \mathrm{~b}$ \\
& 13 & $0.57 \mathrm{~d}$ & $0.09 \mathrm{c}$ \\
$\mathrm{CV}(\%)$ & 12 & $0.49 \mathrm{~d}$ & $0.06 \mathrm{c}$ \\
\hline
\end{tabular}

Means followed by the same letter in the column belong to the same cluster according to the Scott Knott test at the level of $5 \%$ probability.

Coffee Science, Lavras, v. 13, n. 4, p. 510 - 518, oct./dec. 2018 


\section{CONCLUSIONS}

Big Coffee VL. seeds tolerate desiccation to moisture content of $11 \%$ wet basis.

Seeds of the Topázio cultivar have better physiological performance than seeds of the Big Coffee VL. progenies.

The bigger the size of the Big Coffee VL. seeds, the better their physiological performance, exhibiting greater seedling dry matter.

\section{ACKNOWLEDGMENTS}

Our thanks to Embrapa, UFLA, CAPES, FAPEMIG, CNPq, and INCT Café for financial support and the opportunity for carrying out this study.

\section{REFERENCES}

BERJAK, P.; PAMMENTER, N. W. Implications of the lack of desiccation tolerance in recalcitrant seeds. Frontiers in Plant Science, Lausanne, v. 4, n. 478, p. 1-9, Nov. 2013.

BERJAK, P.; SERSHEN, B. V.; PAMMENTER, N. W. Cathodic amelioration of the adverse effects of oxidative stress accompanying procedures necessary for cryopreservation of embryonic axes of recalcitrantseeded species. Seed Science Research, Wageningen, v. 21, n. 3, p. 187-203, Sept. 2011.

BRASIL. Ministério da Agricultura, Pecuária e Abastecimento - Secretaria de Defesa Agropecuária. Regras para análise de sementes. Brasília: MAPA/ ACS, 2009. 399 p.

BRASIL. Ministério da Agricultura, Pecuária e Abastecimento. Instrução Normativa $\mathbf{n}^{\mathbf{0}} \mathbf{8}$, de 11 de junho de 2003. Dispõe de Regulamento Técnico de Identidade e de Qualidade para a Classificação do Café Beneficiado Grão Cru. Brasília, DF, p. 12. 2003.

CARDOSO, B. F. et al. The Italian coffee import: a gravity model analysis. Rivista di Economia Agraria, Firenze, v. 71, n. 1 (Sup), p. 126-133, 2016.

CASTANHEIRA, D. T. et al. Potencial de utilização de características anatômicas e fisiológicas na seleção de progênies de cafeeiro. Coffee Science, Lavras, v. 11, n. 3, p. 374-385, July./Sept. 2016.

COELHO, S. V. B. et al. Alterações fisiológicas e bioquímicas em sementes de café secas em sílica gel e soluções salinas saturadas. Pesquisa Agropecuária Brasileira, Brasília, v. 50, n. 6, p. 483-491, June. 2015.
COELHO, S. V. B. et al. Tolerance of Coffea arabica $\mathrm{L}$. seeds to sub zero temperatures. Ciência e Agrotecnologia, Lavras, v. 3, n. 41, p. 312-321, May./ June. 2017.

CALDAS, A. L. D. et al. Produtividade e qualidade de café cv travessia em resposta à irrigação e adubação fosfatada. Revista Brasileira De Agricultura Irrigada, Fortaleza, v. 12, n. 1, p. 2357-2365, Jan./ Feb. 2018.

ELLIS, R. H.; HONG, T. D.; ROBERTS, E. H. An intermediate category of seed storage behaviour?: I. Coffee. Journal of Experimental Botany, Oxford, v. 41, n. 9, p. 1167-1174, Sept. 1990.

FAVARIN, J. L. et al. Características da semente em relação ao seu potencial fisiológico e a qualidade de mudas de café (Coffea arabica L.). Revista Brasileira de Sementes, Pelotas, v. 25, n. 2, p. 13-19, Dec. 2003.

FERREIRA, D. F. SISVAR: A computer statistical analysis system. Ciência e Agrotecnologia, Lavras, v. 35, n. 6, p. 1039-1042, Nov./Dec. 2011.

FIGUEIREDO, M. A. et al. Exploratory studies for cryopreservation of Coffea arabica L. seeds. Journal of Seed Science, Londrina, v. 39, n. 2, p. 150-158, Apr./ June. 2017.

FLORES, A. V. et al. Efeito do substrato, cor e tamanho de sementes na germinação e vigor de Melanoxylon braúna. Brazilian Journal of Forestry Research, Colombo, v. 34, n. 78, p. 141-147, Apr./June. 2014.

GUEDES, J. M. et al. Divergência genética entre cafeeiros do germoplasma Maragogipe. Bragantia, Campinas, v. 72, n. 2, p. 127-132, Apr/June. 2013.

LAVIOLA, B. G. et al. Influência da adubação na formação de grãos moca e no tamanho de grãos de café (Coffea arabica L.). Coffee Science, Lavras, v. 1. n. 1, p. 36-42, Apr./June. 2006.

MARTINS, A. L. M. et al. Avaliação de progênies dos cafés Catuaí Amarelo e Catuaí Vermelho na região de Pindorama (SP). Bragantia, Campinas, v. 51, n. 1, p. 31-38, Jan/June. 1992.

PARDO, F. F. et al. Qualidade fisiológica de sementes de soja esverdeadas em diferentes tamanhos. Revista de Agricultura Neotropical, Cassilândia, v. 2, n. 3, p. 39-43, July./Sept. 2015. 
ROSA, S. D. V. F. et al. Effects of different drying rates on the physiological quality of Coffea canephora Pierre seeds. Brazilian Journal of Plant Physiology, Londrina, v. 17, n. 2, p. 199-205, Apr./June. 2005.

ROTONDANO, A. K. F. et al. Desenvolvimento vegetativo, produção e qualidade dos grãos de cafeeiro (Coffea arabica L.) sob diferentes lâminas de irrigação. Bioscience Journal, Uberlândia, v. 21, n. 1, p. 65-75, Jan./Apr. 2005.
SANTOS, V. E. et al. Análise do setor de produção e processamento de café em Minas Gerais: uma abordagem matriz insumo-produto. Revista Economia Sociologia Rural, Brasília, v. 47, n. 2, p. 363-388, Apr./June. 2009.

SILVA, J. A. et al. Genetic diversity among coffee tree progenies Big Coffee VL based on growth traits and production. Genetics and Molecular Research, Ribeirão Preto, v. 15, n. 4, p. 1-8, Nov. 2016. 